\title{
Treatise by Olbrycht Strumieński (1573) - The First Polish Book on Hydraulic Engineering
}

\author{
Małgorzata Taborska \\ Jagiellonian University Museum, Poland
}

\begin{abstract}
The treatise by Olbrycht Strumieński is chronologically the first book in Poland, and the second in Europe, describing levelling instruments. A few years after Strumieński's death, the text was published by Stanisław Stroynowski. Until the $19^{\text {th }}$ century, only three Polish-language treatises addressed the problems of levelling. Strumieński described the technique of building and managing fish ponds in Moravia, Bohemia and Poland. The presented surveying instruments and measuring methods are sufficient for the design and construction of a pond that can survive for over 300 years. Strumieński also presented the principles of freshwater aquaculture. Poland, along with Bohemia, Moravia and Hungary, was an exporter of freshwater fish to Western Europe from the $16^{\text {th }}$ to the mid- $18^{\text {th }}$ century.
\end{abstract}

Key words: levelling instruments, levelling treatise, fish ponds

\section{Introduction}

Very little information has survived to this day about the Polish literature on engineering, particularly publications on levelling and hydraulic engineering. Geometria regis (Lat., Kraków, 1450) by Marcin Król from Żurawica (ca. 1422-1460), one of the first Polish treatises on geometry and surveying, does not provide descriptions of levelling instruments. Nothing is known about the contents of another book on surveying, the lost work by Andrzej from Łęczyca O nauce mierniczej [About measuring science] (1555). For these reasons, the oldest Polish-language book on engineering containing descriptions of measuring instruments is considered to be a treatise on geometry by Stanisław Grzepski Geometria, to jest miernicka nauka...[Geometry in surveying science...] (Kraków 1566). The only surveying instruments mentioned by the author are "alidade with dioptre", rope (a kinde of surveyor's chain) and staff [1]. For the first time the problems related to levelling, along with a detailed description of techniques and instruments, were

Corresponding author: Małgorzata Taborska, Jagiellonian University Museum, Poland. discussed by Olbrycht Strumieński (1600-1605) in his treatise O Spráwie Sypániu, Wymierzániu, y Rybieniu stawów... [On making, coffering, surveying, and stocking ponds with fry...] (Kraków, 1573). This is the second book published in Europe addressing the issues of hydraulic engineering. The first book on this subject was Joanni Dubravii de piscinis... by Jan Dubrowiusz (Wrocław 1547), and its Polish version O rybnikach y rybach ...[About fishponds and fish] was published 87 years after the treatise by Strumieński [2]. Unlike Dubrawiusz, Strumieński provided a lot of practical and technical information about carrying out field work, such as finding the right site, the measuring procedure and earthworks. $\mathrm{He}$ also discussed in detail different types of ponds and the basics of fish farming [3].

\section{Treatise by Strumieński}

Bibliografia Polska [Polish bibliography] mentions just two copies of the work by Strumieński that have survived to the $19^{\text {th }}$ century, published in 1573 and 1605 [4]. The treatise must have been popular, considering the fact that after the death of Strumieński Jan Januszowski (?-1588) published a reprint in 1605, 
arguing that "The book, however short, is very useful to all landlords. It was unavailable for a long time, but many people wanted to have it and eagerly asked for it to be printed again" [5]. In 1897 Feliks Kucharzewski (1849-1935) published in Kraków a reprint of a copy from 1573.

Just four years after the second release of Strumieński's treatise, the text was published by Stanisław Stroynowski (1580-?) in his work Opisanie Porządku Stawowego y przestróg niektórych domowego gospodarstwa...[Fish ponds management...] (Kraków 1609). Then it was published again in $1636[1,4,6]$. Stroynowski preserved the text by Strumieński, but added more information on aquaculture and fish species [3]. In 1860 the treatise was reprinted as a supplement to a book on fish farming in Poland by Zygmunt Gawarecki and Albin Kohn, Polskie stawowe gospodarstwo [Polish pond farm] (Warszawa 1860).

Strumieński's book has an extremely practical value. It is written in simple, clear language, and contains many technical notes which reflect the author's own experiences [6]. Apart from a detailed description of the instruments, and levelling and hydraulic engineering works, it also presents basic information on the management of fish ponds: how to build and use small ponds for fish storage, how to hatch and rear fry, and information on the major species of fish. Strumieński described two types of pond: 1) ponds fed with rainwater and wastewater, often created in a system of ditches draining adjacent swampy areas; 2) ponds fed with water from streams and rivers, established in river valleys and old river beds, for which a greater budget was required to protect them against flood waves $[5,7]$.

\section{Management of Fish Ponds}

Strumieński presented practical and theoretical information on the construction of fish ponds, including their whole infrastructure. The description refers to ponds in Bohemia, Moravia and Poland, characterized by a complex system for water supply and discharge. This was related to the management plan, which involved the intermittent filling with water and drying of the pond. The pond stayed filled with water for several years (5-10). At that time it was used for aquaculture, and was partly emptied on average every 2 years. At the second stage the pond was dried out for 3-4 years and was used as arable land. Millet, wheat, manna grass and barley were grown in the first year, wheat and rye in the second year, rye and wheat in the third, and oats in the fourth year $[3,5,7]$. If growing cereals was impossible, then the empty pond was used as a meadow or pasture. In the process of pond drying, the soil lost acidity, which eliminated the reed, sweet flag and reed beds [8]. It was also important to destroy parasites: tapeworm eggs (by thorough drying of the bottom of the pond at $18-20^{\circ} \mathrm{C}$ ) and the common fish louse Argulus foliaceus Linnaeus, 1758, whose developmental forms die after three hours in dry soil. Drying also significantly reduced the population of leeches [9]. Then, the system of drains was repaired and improved, the dykes were inspected, and the pond refilled with water [5, 7]. In the Archives of the Dukes of Pszczyna from the $18^{\text {th }}$ century, descriptions of a management plan for a system of ponds in the Pszczyna region were preserved. As these descriptions read, every ten years on average the Bieruński Great Pond (600 ha) was drained for 3 years. The empty pond was used for growing cereals (usually oats), and then a meadow was established in the second year. In the last year the land was used for grazing, which made the soil fertilized and properly compacted. Then repairs were done and wooden hydraulic engineering structures were replaced (between the end of August and the beginning of September). The pond was filled with autumn rainwater. Arable fields provided more profit (sometimes 3-fold greater) than aquaculture. For example, the profit on cereals grown in the Bieruński Great Pond was 3,700 florins in 1758 and 8,200 florins in 1759, while the sales of fish generated 1350 
$\mathrm{fl}$ in 1757 and $2082 \mathrm{fl}$ in 1763 [8].

Thanks to the extensive discharge system, digging a dyke to drain water was not necessary, unlike in "Ruthenian-design ponds" [3, 5, 7]. Dykes built consistently with engineering principles strengthened over the subsequent decades, and ponds could survive for more than 300 years. Many of them were destroyed and damaged during wars, especially during the Swedish Deluge (1655-1660) and WWI and WWII [10-12]. Some of them were demolished intentionally when changes in land use were introduced (between 1650 and 1850).

Strumieński mentioned the following principles for establishing ponds $[5,7]$ : the water level should be at least 4 ells $(2.34 \mathrm{~m})$, but over 5 ells is recommended $(2.93 \mathrm{~m})$, to allow the fish to survive the winter. The unit of measurement, łokieć handlowy krakowski (the Cracow ell), equal to two feet $(58.6 \mathrm{~cm})$, was used in the Crown of the Kingdom of Poland from 1565. The length of Cracow ell changed. It was $0.5236 \mathrm{~m}$ in the $12^{\text {th }} \mathrm{c} ., 0.6466 \mathrm{~m}$ in the $13^{\text {th }} \mathrm{c} ., 0.625 \mathrm{~m}$ in the $14^{\text {th }} \mathrm{c}$., $0.586 \mathrm{~m}$ in the mid- $16^{\text {th }} \mathrm{c}$., and $0.596 \mathrm{~m}$ in $1836-1857$ [13]. The dyke should be elevated 4 or 5 ells $(2-3 \mathrm{~m})$ over the normal water level to retain water during spring snowmelt and create a reserve for times of drought. The pond must not be established on sandy soil; clay is best for the purpose. Terrain: the bottom of the pond and the embankment should be thoroughly cleaned of trees, bushes, faggot and any fragments of wood, as they create potential sites of water escape. Once the dykes are constructed, their crown and the base should be reinforced with fascine (in spring or autumn). This technique is still used [14].

\section{Construction Works and Instruments}

The work described by Strumieński concerns the purely practical aspects of constructing the pond and related infrastructure: inspection of the site, setting and stabilisation of landmarks, and the construction of earth structures and their further repairs. Back then there were no geodetic regulations that would require the preparation of an architectural design, its adaptation and positioning it on a map, linking to a triangulation and levelling network, or as-built documentation. Most measurements were just simple levelling operations that did not require particular accuracy. Until the $20^{\text {th }}$ century a levelling instrument, a horizontal level, a clinometer, a plumbline or a water level were sufficient for this purpose. The major task was to measure and shape the downslope to ensure the undisturbed flow of water in the desired direction, and to erect structures anticipating the risk of flood waves, high water, and the direct consequences of snow melt or prolonged rainfall (Fig. 1). The second task was the appropriate shaping of dykes to achieve the correct slope of supporting embankments (Fig. 2).

\subsection{Instruments Described in the Treatise}

Strumieński focused on three instruments: synbalance, archipendulum (rope-level) and water level. He used such terms as krokwica meaning small-rafter (probably a type of level, made of slats and a plumb bob), sznur mierniczy meaning gunter's chain, wirguła - a clinometer, and spekuła ("vertically hung mirrors", i.e., a type of optical square) [15]. He also mentioned a range rod, used as a level staff, either notched or with a paper disc.

Notches were cut according to the appropriate graduation, spaced in ells and their fractions. The current standards require accuracy to the nearest 10 $\mathrm{mm}$ per $1 \mathrm{~m}$ (technical levelling), and level staffs are made with a centimetre scale, enabling the estimation of the measurement with accuracy to the nearest $1 \mathrm{~mm}$. Range rods proposed by both authors had notches made at 1-finger intervals (one inch $=2.44 \mathrm{~cm}$ ), which allowed for estimating the measurement with an accuracy of $1.22 \mathrm{~cm}[5,7,11]$. Sawicki [16] indicated that the accuracy of level staffs proposed by Dubrawiusz was not greater than $1 / 4$ of an ell (i.e., approx. $15 \mathrm{~cm}$ ). This degree of accuracy was sufficient for the correct performance of levelling works and building fish pond infrastructure. It allowed 
for the rough estimation of the height of the dyke, which was later carefully levelled using a śródwaga (synbalance) $[6,16]$.

Dubrawiusz described only two instruments - an enormous 6-metre chorobates and a small pocket-size dioptra [2]. Strumieński mentioned three instruments, and Stroiński added waga sklenicza (synbalance with a cup) and waga żuławska (water level from Żuławy) to this list (Figs. 11 and 12). If we compare the figures presented by the two authors, we can see that those by Strumieński are simplified, schematic, pictogram-like (Figs. 3a, 5a, 8a), while Stroynowski shows many details and even uses shading to create a three-dimensional effect (Figs. 3b, 5b, 8b).

Off all the three instruments mentioned by Strumieński and Stroynowski, two allow for the measurement of direct differences in level by measuring the tilt of a bar (archipendulum) or rope (synbalance). The water level is the only device for taking measurement with the aiming line, which makes its operation similar to contemporary dumpy levels.

- Synbalance (Figs. 3a, b)

Both authors give almost identical descriptions of this instrument. It is made of dry fir timber, white and lightweight wood, planed by the carpenter with an accuracy of "half a hair per metre". The bar is 8 ells long $(4.69 \mathrm{~m})$, and an eighth of an ell wide (approx. 7 $\mathrm{cm})$. A small rafter is attached in the middle - a horizontal level not longer than one ell $(58.6 \mathrm{~cm})$. The levelling element is a lead weight on a thin rope or string, passing to the other side through a hole in the bar. The instrument is attached to two notched sticks with knives (Fig. 3b). The measurement is quite labour-intensive and is done along the established line from the river bed, supplying water, to the target location of the fish pond (Fig. 4). Each measurement using the synbalance is taken in two positions (with the instrument rotated by $180^{\circ}$ ). The levelling line is also measured twice (there and back), and the convergence of the starting point is verified. The measurement required two experienced assistants. Strumieński considered it necessary to take additional measurement using, for example, an archipendulum.

- Archipendulum (Figs. 5a, b)

A balance on a rope with a metal plate was a brass triangular plate with a plumb bob, hanging on a rope, a type of rope-level. The plumb bob was suspended centrally along the side, on a rope, so it covered the check hole near the bottom apex of the triangle. The plate, measured precisely with a compass, was an equilateral triangle with a side length of approx. $7 \mathrm{~cm}$. The whole implement was suspended on a 16-ell-long rope $(9.376 \mathrm{~m})$, made of threads (preferably hemp) tightly twisted and painted white, which kept the rope resistant to water and stretching. The rope was tied to two rods and stretched to make it "taut" (Figs. 5b, 7). The measurement using the archipendulum was taken in the same way as using the synbalance, there and back, but the instrument remained in one position (Fig. 6). Levelling accuracy could be problematic, and measurement should be verified with another instrument. It was impossible to take measurements during rainfall, or windy or very humid weather. Strumieński recommended the archipendulum when working in forests or shrubwood because the instrument was easy to manipulate.

Water balance - water level (Figs. 8a, b; 9)

This is an instrument installed on a stand, and consists of a water tray, sights and additional plumblines, as well as two tilting screws used for levelling. Of all the levelling instruments Strumieński most appreciated the water balance. He noted that it is fundamental that the instrument is made of good quality materials by masters of the craft. The wooden tray - a ruler made of a planned board, 8-ells long $(4.684 \mathrm{~m})$ with a groove in the midline, 2-fingers thick (approx. $5 \mathrm{~cm}$ ) was less recommended than the tray made of metal sheet. A tray made of iron (steel) or brass sheet, 4-ells long (2.382 m), 2-fingers deep and wide (approx. $5 \mathrm{~cm}$ ), had ends blinded with stops with holes (sights), positioned above the water table (Fig. 
8c). The stand was made of a 2-ell-long pole $(1.17 \mathrm{~m})$, covered with metal at the end, so it could be easily driven into the ground (Fig. 8b). The tray was attached at the top and was rotary, which enabled the taking of measurements in all directions. Stroynowski did not value this instrument much, claiming that there were no good craftsmen in Poland who could handle its manufacture. He recommended that a pipe should be made by a gunsmith, preferably of brass or steel recovered by forging old scythes. He also paid a lot of attention to the design of the stand. The bed for the tray was made of two metal sheets, 3-ells long (1.75 $\mathrm{m})$, three-fingers wide $(7.32 \mathrm{~cm})$. They were nailed to the pole from the bottom, and the fastening was reinforced with a four-corner band, holding both the tray's bed and the tray.

During measurement a target attached to a rod was used. The measurement procedure started with the setting of the instrument - the authors instructed filling it with water until "it leaks from both sides". At first, the initial elevation of the measurement had to be established. The stand was tall enough so the surveyor did not have to lean. The distance between the instrument and the target was one to two staja (134-268 m, one staja staropolska was $134 \mathrm{~m}$; for comparison the staja nowopolska used after 1819 was $1066.8 \mathrm{~m}$. The measurements were taken in the same fashion as when using dumpy-levels (Fig. 10), in two positions of the telescopic level (in this case the tray).

These are the instructions given by Stroynowski on taking measurements: "Be standing on the bank of the river and drive the ranging rod with a paper target into the ground. Walk away from the rod and the target. Drive the rod into the ring (on the stand) always mind the appropriate depth. The tray should be one and a half or two ells above the ground level, for convenient measurement without leaning, which also makes measurement more precise. Look through the sights in the tray above the water level, as if aiming a gun at a bird. Make a notch under the paper, and the second notch on the rod, where the water reaches.
Take a measurement in the opposite direction, at a distance of one or one and a half staja [139-268 m; 17].

- Other instruments mentioned by Strumieński

The waga skleniczna (synbalance with a cup) was a simplified variant of the synbalance, in which the level (small rafter) was replaced with a cup filled with water. The waga żuławska, a water level from Żuławy, was a simplified variant of the water level. Żuławska is an adjective referring to the region of Żuławy Wiślane, located in the estuary of the Vistula River, delineated by the rivers Wisła, Leniwka and Nogat, and the Vistula Spit. Over $1 / 4$ of this area lies below ground level (450 out of $1700 \mathrm{~km}^{2}$ ). The instrument consists of a wooden tube attached to a stick. At both ends the pipe is half-blinded, and when tilted water pours from the inside through a hole. The instrument had one screw for adjusting elevation. Both instruments were structurally very simple and inaccurate in operation.

\subsection{Levelling with the Water Level - Problems}

Measurements were taken by a geometric levelling technique, using instruments similar to the contemporary dumpy level and Y-level. A surveyor uses the aiming line to read values from the level staff. Telescopic levels are mounted on a stand in a similar fashion as water balances. The process of measuring is associated with same problems, including the risk of instrument error, measuring error, and operator error.

The most important measuring error is incorrect positioning of the instrument (e.g., levelling error). In the builder's level, levelling is done with the spirit-level, mounted on the top of the telescope. In water balances water was sometimes coloured, or a piece of wood was placed inside the tray. The piece of wood helped operate the instrument, and when it was in the middle of the tray (in the long axis), the instrument was levelled. Another problem concerned placing the staff precisely in the horizontal position. A measurement error could also be caused by the refraction of light waves. This problem particularly 
occurs in areas near water bodies. The aiming line bends downwards when the water is colder than the air, but bends upwards when the water is warmer than the air. This phenomenon also has a significant effect on measurements taken on the land (Fig. 13).

The most important instrument error is caused by the non-parallel position of the aiming line and the long axis of the instrument (the axis of the spirit level in modern levels). In the water balance the error can be caused by the incorrect position of the operator. When the position of the instrument is too low or too high the surveyor looks at an angle. Other causes may be the incorrect manufacturing of the instrument (imprecisely placed sights, uneven elements, etc.). Errors associated with this are to some degree eliminated by taking measurements with the instrument in two positions.

Stroynowski recommended levelling from the half-way point: taking measurements aiming at the rod in one direction and then in the other direction. This method is biased with a smaller error than levelling in a forward direction, because the error value is halved (Fig. 14).

\section{Levelling Instruments in Polish Treatises Before the Early $19^{\text {th }} \mathrm{c}$.}

Before the $19^{\text {th }}$ century the problems of levelling and a description of instruments were mentioned only in three Polish-language textbooks. Józef Naronowicz-Naroński, in his book Geometria albo rozmiar [Geometry or measuring ] (mscp 1659), mentions the archipendulum with scales and a plumbline (clinometer), a water balance and an astrolabia otherwise known as a circumferentor (Fig. 15).

Naroński's water balance consisted of a bar with a groove, with a small glass cup at both ends, bottomless and serving as sights (Fig. 16). The water inside the instrument was coloured red or black, and the operator aimed above the water level in both cups (Fig. 10). Stanisław Solski, in his book on architecture, Architekt Polski [The Polish Architect] (Kraków
1690), mentions only the rope-level (synbalance), with an approx. $3 \mathrm{~m}$-long rope and an approx. 3 $\mathrm{cm}$-wide metal plate. Another book about practical geometry, Jeometrya Praktyczna [Practical geometry] (Warszawa 1786) by Ignacy Zaborowski, was the first treatise on modern levelling instruments in the Polish literature [6]. Zaborowski defined these instruments as równowagi czyli libellae [balances in the meaning of levels]. The water balance described by him is a metal tube with two glass pipes at both ends (the same as the instrument by Naroński). Zaborowski recommends using a spirit level, which is a glass level filled with wine vinegar with a trapped air bubble (Fig. 17). It is mounted on a "brass or wooden base" with sights, that is an alidade, or on a perspective, that is a telescope. The stand with a screw and a toothed wheel enabled the appropriate tilting of the instrument and its rotation. It is in fact a dumpy level with a horizontal level and crossing lines. He also described a professional staff, at least $3 \mathrm{~m}$ tall, consisting of two sliding parts and a mobile target (Fig. 18). He also presented a template for a simple levelling report, and how to complete it and prepare a sketch of the measured site.

During the operation of the Commission of National Education (1781-1794), curricula for schools of various levels of education were written, including programme textbooks. Many of them were books translated from foreign languages and approved in a competition-based procedure. For courses on geodesy the Commission approved a textbook on geometry by Simon L'Huillier, Geometry for national schools (1781), translated by Andrzej Gawroński (1740-1813). In 1825 the first Polish polytechnic was opened in Warsaw (1825-1831). The basic course book was Jeometrya praktyczna [Practical geometry] by Ignacy Zaborowski (1786, supplemented and updated in the edition of 1820). As mentioned in the Scientific Instructions for the Polytechnic Institute ..., prepared by the Polytechnic Council, measurements during the practical course were taken using a water level (niveau 
d'eau) and a triangular inclinometer (niveau de pente acc. to Antoine Chezy). During the classes the design and operation of eclimeters (devices for topographic levelling) were explained. As indicated in the inventory taken in 1831 (closure of the school), these were: an eclimeter, a device for measuring angles of slope; a dioptra with a sighting tube or a brass sight rule [used with a plane table]; a cylindrical pantometer for measuring angles; a calculator invented by Zieliński [6].

\section{Traditions Related to Fish Ponds}

There were certain reasons for which Bohemian and Polish books were pioneering in Europe. Hungary, Poland, Moravia and Silesia were the main European regions producing freshwater fish between the $16^{\text {th }}$ and $\operatorname{mid}-17^{\text {th }}$ century $[10,12]$. The most popular freshwater fish in Poland, carp Cyprinus carpio L. 1578, came from northern Italy, Bavaria and southern Bohemia via Moravia and the Moravian Gate. Rapid urbanization in Western Europe, damage caused by the Thirty Years' War, etc. caused a shortage of freshwater fish. However, Poland had many natural lakes (mainly in northern and central Poland), and also numerous smaller and larger ponds created by filling pits on clay or excavations with rainwater. The tradition of eating and breeding fish was long, especially since the Slavs were linked with inland waters and established old settlements near rivers and lakes. There were also regions with limited numbers of natural water bodies, distant from the sea, but with landscape and soil suitable for establishing semi-natural lakes and ponds (Silesia, Lesser Poland). These regions were relatively densely populated and were located within a distance enabling food trade with large towns such as Kraków, Wrocław, Poznań, Leszno and Kalisz. Fish was considered as a non-meat food as early as at the turn of the $12^{\text {th }}$ century, and in the Christian tradition the consumption of meat was forbidden for more than 180 days in a year. Thus, there was a guaranteed demand for fish.
The first systems of carp ponds were established in Poland near Cistercian monasteries after the $11^{\text {th }} \mathrm{c}$. Then in the $12 / 13^{\text {th }} \mathrm{c}$. the first large systems of ponds were created near Oświęcim, Zator, Rybnik, Łowicz and Milicz [11]. The largest fish ponds and their largest clusters were located in Silesia. In the $16^{\text {th }}$ century fishery was one of the major branches of the Silesian economy, following mining, metallurgy and weaving. Most important fish ponds were in the region of Milicz (still in operation), Rybnik and Pszczyna (operating until the $20^{\text {th }}$ c.) [11].

The Milicz region had the largest system of fish ponds in Europe. Fish from there were supplied to Silesia and Greater Poland. As early as about 1115 local land was owned by the Wrocław Chapter and the Cistercian monastery, with its seat in Libiaż̇. Back then, there was a system of natural lakes and small man-made ponds, created in natural land depressions, and reinforced with small dykes, covering about 2000 ha in total. Some ponds were created in basins created during the extraction of bog iron (limonite). At present, it is the largest nature reserve in Poland, and one of the most valuable ornithological sites in Europe [18]. The Rybnik-Pszczyna region lies on the border of Silesia and Lesser Poland, but fish from here used to be exported to Moravia and Slovakia. Local fish was supplied, for example, to Kraków, back then the capital of Poland. In the $14^{\text {th }}$ and $15^{\text {th }}$ centuries, the fish were floated to Kraków in special boxes, half filled with water, pulled behind canoes. After selling all the fish, the boxes were sold as firewood [10, 11].

At the very beginning, fish were reared in small man-made ponds used for the storage of caught fish. In towns located by large rivers and lakes there were fishing guilds as early as in the Middle Ages, and they had their own marinas, waterfronts, streets and squares. The guilds also had clay-pits, usually near the market place. In the villages and land holdings, farms and manors, fishing was not formally organized (Ger. Wide-Fischerei), but fish ponds were very popular [11]. For example, in the second half of the $15^{\text {th }} \mathrm{c}$. in 
Silesia the total surface area of fish ponds owned by dukes was over 10000 ha, those owned by nobles over 40000 ha, and country men and townspeople owned up to 10000 ha. In the grounds of manor houses fish were kept for feasts. For example, northern pike were kept in separate small ponds near the manor, and fed with live small fish. In towns, crayfish were kept in ponds and special basins [18]. The oldest description of trout farming in Poland comes from 1532, from the Soła river [19].

In clay pits and ponds peasants kept mainly tench, crucian carp and carp, but in the $16^{\text {th }}$ century the transfer system of farming was introduced and the demand for carp fry was high. Most fish ponds were converted into hatcheries and basins for fry farming. Fish for consumption were farmed in ponds owned by nobles and dukes. Such ponds were stocked with 2-3 year-old fry, and after two years "consumable fish" were harvested. Large fish farms provided jobs for poor and landless peasants, who were allocated specific duties such as attending ponds, dykes and watch towers. They worked as guards, fishermen, raftsmen, carters and sorters, mended fishnets, and did other work on the fish ponds. Peasants paid rent to their landlord by harvesting, sorting and transporting fish and doing repair works on the ponds.

After the second half of the $15^{\text {th }} \mathrm{c}$. the infrastructure of fish ponds was developed and improved (for example, monks were introduced). The transfer system also came into use (fish at different ages were moved to other ponds). This reduced the time necessary for growing fish from the initial 5-7 years to 3-4 years, and fish were sorted by species and health status. In the second half of the $16^{\text {th }} \mathrm{c}$. carp accounted for about $75-80 \%$ of all fish farmed in Milicz ponds [18].

Five phases can be identified in the development of fish pond farming in Poland: rapid growth $\left(12^{\text {th }}\right.$ c.-1650), decline (1650-1868) and development of modern fish pond farming (1868-1939), stagnation (1939-2000) and dynamic growth after 2000. The first decline in the popularity of fish pond farming in Poland took place in the second half of the $17^{\text {th }} \mathrm{c}$. The unstable political situation and prolonged wars contributed to this: at the time of the Swedish Deluge (1655-1660) almost half of the ponds in Poland were destroyed [10]. Agriculture had also changed: new varieties of cereals and root crops were introduced (e.g., potatoes), the three-field crop rotation system was abandoned, growing aftercrops became popular, and more productive breeds of livestock came into use. All this required more farming land. The political system had changed as well, and serfdom gradually disappeared. In Silesia prolonged droughts caused a water deficit after 1650 [18]. Not earlier than about 1850 modern methods of fish farming were introduced, and the time necessary to grow fish was reduced to 2-3 years. The region of Lower Silesia was back then the main supplier of freshwater fish to the German market [8]. Since 2000 fish pond farming has mainly relied on farming carp (2/3 of production volume), Salmonidae and crayfish [20].

\section{Fish Farming}

In the $16^{\text {th }}$ century the most popular farmed fish were carp, northern pike and zander. About $15-20 \%$ of the harvest was other species: dark fish - crucian carp, burbot, tench, weatherfish, catfish, and white fish - common bream, roach, perch, gudgeon, ide, ruffe, break, etc. [20]. Strumieński particularly recommended tench because of its tasty flesh. He considered some species of fish to be difficult to farm and not very profitable: vimba, Atlantic salmon, trout, eel (because they escape from the pond), and cat fish (because they mutilate and eat other fish). Gołębiowski lists 35 species of freshwater fish used in Polish cuisine, but also crayfish, turtles, snails, oysters and caviar [21].

Fish was also served at the royal table. The Czechowizna fish pond near Knyszyn, built by order of Queen Bona in 1560 for Zygmunt August, covers 480 ha. The preserved records from the late $16^{\text {th }}$ 
century documenting food supplies to the court of King Zygmunt III show that freshwater fish prevailed, although sea fish were also imported: herrings, eels and Atlantic salmon [22]. The royal court most often ordered northern pike, carp, common bream, ide, dace, vedance, perch, tench, zander, burbot, barbel, trout, and asp from the Vistula River [6]. All species of fish were either salted, smoked, dried, or pickled and stored in barrels. Live fish were transported in barrels, and later kept in wooden cages that were placed on the edges of ponds, or sometimes in river pools [6].

\section{References}

[1] Kucharzewski, F. 1889. O poczatkach piśmiennictwa technicznego $w$ Polsce (About early publications on engineering in Poland). Warszawa: J. Sikorski.

[2] Dubravius, J., ca 1660. O rybnikach y rybach, które się w nich chowaiq.... (About fish ponds and fish species kept in them). Kraków: Printhouse of Woyciech Siekielowic.

[3] Kucharzewski, F. 1897. Olbrychta Strumieńskiego O sprawie, sypaniu, wymierzaniu i rybieniu stawów 1573 , (On the design, construction, measurement and stocking of fish ponds by Olbrycht Strumieński), Kraków: Akademia Umiejętności.

[4] Estreicher, K. 1830. "Bibliografia Polska obejmująca druki stuleci XV-XVIII w układzie abecadłowym. (Polish bibliography of printed materials from the $15-18^{\text {th }} \mathrm{c}$. in alphabetic order)." Kraków 3 (28): 342-343. https://www.estreicher.uj.edu.pl/home/.

[5] Stroynowski, S. 1609. Opisanie porządku stawowego .... (Fish pond management). Kraków: Bazyli Skalski.

[6] Sawicki, K., 1970. Jana Dubrawiusza, biskupa czeskiego nauka niwelacji. (Science of levelling by Jan Dubrawiusz, a Bohemian bishop), Kwartalnik Historii Nauki i Techniki. 15 (4): 759-774.

[7] Strumieński, O. 1605. O sprawie, sypaniu, wymierzaniu i rybieniu stawów... (On making, coffering, surveying, and stocking ponds with fry...), Kraków: Printhouse of Łazarz.

[8] Marcinek, R., 1993. Wielki Staw Bieruński i jego pozostałości. (The Great Pond Bieruński and its remnants), Bierun. http://docplayer.pl/2789034-Romanmarcinek-wielki-staw-bierun-ski-i-jego-pozostasosci.htm.

[9] Kramer I., Antychowicz J., 2017. "Profilaktyka i terapia chorób ryb. (Prevention and treatment of diseases in fish).” In: Kowalska-Góralska, M. (Ed.) Akwakultura karpia - aspekty ekonomiczne, ekologiczne i prawne (Carp aquaculture - economic, ecological and legal aspects), Poznań: Polskie Towarzystwo Rybackie: 59-77.
[10] Chmielewski, S. 1965. "From the History of Freshwater Fisheries in Poland." In: Backiel, T. (Ed.), Fresh-water Fisheries of Poland. XVI Limnologorum Conventus in Polonia MCMLXV. Kraków: 3-13.

[11] Cios, S. 2016. "The History of Aquaculture in Poland." In: Bonow, M., Olsén, H., Svanberg, I., Historical Aquaculture in Northern Europe. Stockholm, pp. 59-68.

[12] Strumieński, O. 1573. O sprawie, sypaniu, wymierzaniu $i$ rybieniu stawów... (On making, coffering, surveying, and stocking ponds with fry...). Kraków: Łazarz Andrychowic.

[13] Kozera, M. 1988. "Łokieć jako miara długości w średniowieczu. (Ell as a measurement of length)." Problemy 2: 125.

[14] Guziur, J., Woźniak, M. 2006. Produkcja ryb w matych zbiornikach (Fish Farming in Small Ponds). Warszawa: Oficyna Wydawnicza Hoża.

[15] Kucharzewski, F. 1899. O narzędziach niwelacyjnych używanych w Polsce w wieku XVI-ym. (Levelling instruments used in Poland in the $16^{\text {th }}$ century). Przeglad Techniczny. 37 (12-13): 193-198, 209-212.

[16] Sawicki, K., 1964. Pięć wieków Geodezji polskiej. Szkice Historyczne od XV do XIX wieku. (Five centuries of geodesy in Poland. Historic essays from the $15^{\text {th }}-19^{\text {th }}$ centuries). Warszawa: PPWK.

[17] Stroynowski, S., 1636. Opisanie porzqdku stawowego .... (Fish pond management). Kraków: Printhouse of Franciszek Cezary.

[18] Bohdanowicz, J., 2011-2015. Gospodarka stawowa w Dolinie Baryczy (Fish pond farming in the Barycz River valley). Stawy Milickie.pl, accessed on 21. 02. 2019.

[19] Rybarski, R. 1931. Gospodarstwo Księstwa Oświęcimskiego w XVI wieku. (Economy of the Duchy of Oświęcim in the $16^{\text {th }}$ c.). Kraków: Jagiellonian University Press.

[20] Lirski, A., Myszkowski, L., 2017. "Polska akwakultura w 2016 roku na podstawie analizy kwestionariuszy RRW-22. (Polish aquaculture in 2016 based on the analysis of RRW-22 questionnaires)." Komunikaty Rybackie 6: 20-26.

[21] Gołębiowski, Ł., 1830. Domu i dwory przy tem opisane apteczki, kuchni, stołów, uczt, biesiad (...) wszelkich zwyczajów dworskich i różnych obyczajów szlacheckich. (Of homesteads and manors, with a description of apothecary, kitchen, dining table, feasts (...), all manorial traditions and customs followed by noble men), Warszawa: published by the author.

[22] Michalewicz, J. 1965. “' $Z$ badań nad konsumpcją spożywczą w Polsce: kuchnia królewska Zygmunta III. (Studies on food consumption in Poland: royal cuisine of King Zygmunt III)." Kwartalnik Historii Kultury Materialnej 13 (4): 701-718. 